\title{
PENGARUH KEBIJAKAN WAJIB SALAT BERJAMAAH TERHADAP ETOS KERJA PEGAWAI DAERAH KABUPATEN ROKAN HULU
}

\author{
Yuni Raf ta1), Wiwit Sylviana Agustin2), Rizki Adhiputra3), Siti Arni Wulandya4) \\ Jurusan Statistika, Fakultas Matematika dan Ilmu Pengetahuan Alam,
}

\begin{abstract}
ABSTRAK
Kewenangan lebih luas pemerintah daerah sejak adanya otonomi daerah menuntut para pegawai daerah untuk memiliki etos kerja yang tinggi. Pembentukan dan penguatan etos kerja tidak semata-mata ditentukan oleh kualitas pendidikan atau prestasi yang berhubungan dengan profesi dan dunia kerja, tetapi juga bersumber pada iman yang bisa ditumbuhkan melalui kegiatan ibadah. Rokan Hulu, salah satu kabupaten di provinsi Riau mempunyai suatu peraturan yang mewajibkan para pegawai muslim untuk salat berjamaah. Peraturan ini dituangkan dalam Peraturan Bupati Rokan Hulu Nomor 18 Tahun 2011 tentang Kewajiban Bagi Pegawai Muslim untuk Salat Zuhur dan SalatAsardi Masjid Agung Pasir Pengaraian. Penelitian ini bertujuan untuk melihat pengaruh kebijakan tersebut terhadap etos kerja para pegawai daerah. Pengumpulan data dilakukan dengan kuesioner dan wawancara. Hipotesis awal adalah terdapat pengaruh positif antara kebijakan wajib salat berjamaah terhadap etos kerja pegawai daerah. Data dianalisis dengan menggunakan Analisis Deskriptif dan analisis regresi linier sederhana. Hasil analisis deskriptif menunjukkan bahwa sebagian besar Pegawai Daerah setuju dengan kebijakan dan optimis kebijakan ini akan berdampak positif terhadap etos kerja. Menggunakan analisis regresi linier sederhana didapatkan bahwa kebijakan wajib salat berjamaah berpengaruh positif sebesar 0.843 terhadap etos kerja pegawai daerah Kabupaten Rokan Hulu. Hasil tersebut didukung oleh pernyataan Kasubag Kegiatan Keagamaan Sekretariat Daerah Rokan Hulu, Bapak Damrah S.Sos, bahwa penerapan kebijakan wajib salat berjamaah zuhur dan ashar merupakan suatu langkah untuk membina akhlak pegawai daerah agar bisa terhindar dari praktek-praktek curang yang saat ini marak terjadi.
\end{abstract}

Kata Kunci : Salat Berjamaah, Etos Kerja, Regresi Linier Sederhana, Kebijakan, Rokan Hulu 


\section{PENDAHULUAN}

Sejaktahun 1999 Pemerintah Pusat telah membuat kebijakan tentang Otonomi Daerah dengan dikeluarkannya Undang-Undang No. 22/1999 tentang Pemerintah Daerah. Undangundang ini telah mengubah peta politik dalam penataan kewenangan dan kewajiban pemerintah. Pemerintah daerah yang semula dikendalikan pemerintah pusat menjadi otonomi daerah. Menurut undang-undang tersebut pihak pemerintah daerah memiliki kewenangan yang lebih luas atau lebih besar dalam mengatur pemerintahannya sendiri.

Kewenangan lebih luas tersebut, menuntut pemerintah daerah untuk lebih giat dan lebih peka dalam menghadapi berbagai permasalahan dalam pembangunan daerah. Para pegawai pemerintah daerah dituntut untuk memiliki etos kerja yang tinggi agar semua pekerjaan yang berhubungan dengan pembangunan daerah dan pelayanan terhadap masyarakat dapat dilaksanakan dengan baik.

Etos kerja merupakan cerminan dari sikap hidup yang mendasar dalam menghadapi dunia kerja. Pembentukan dan penguatan etos kerja tidak semata-mata ditentukan oleh kualitas pendidikan atau prestasi yang berhubungan dengan profesi dan dunia kerja, tetapi juga ditentukan oleh faktor-faktor lain seperti suasana batin dan semangat hidup yang bersumber pada keyakinan atau iman
(Asror, 2004). Etos kerja merupakan sikap terhadap pekerjaan, sehingga etos kerja yang baik juga akan menghasilkan kinerja yang baik pula tentunya akan berpengaruh signif kan terhadap kemajuan lembaga/ instansi tempat bekerja (Baddu, 2007).

Krisis multidimensi yang melanda bangsa ini merupakan salah satu bukti semakin menurunnya etos kerja di kalangan pemerintah. Perlu adanya perhatian yang serius oleh berbagai pihak untuk meningkatkan etos kerja pemerintah melalui kebijakan yang bisa memperkuat kembali religiusitas pemerintah dengan berbagai aktivitas keagamaan. Salah satunya yaitu berupa pembiasaan salat berjamaah.

Salat merupakan salah satu kewajiban umat Islam, sebagai tiang agama, dan salat juga dapat mencegah perbuatan keji dan munkar. Salat yang dilakukan secara berjamaah memiliki banyak keutamaan, salah satunya sebagai sarana penyatuan hati dan $f$ sik serta saling mengenal satu sama lain sehingga akan timbul rasa persaudaraan sesama muslim serta sebagai alat untuk melatih mental dan kedisiplinan.

Rokan Hulu, salah satu kabupaten di provinsi Riau, mempunyai suatu peraturan yang mewajibkan para pegawai muslim salat Zuhur dan Asar berjamaah di Masjid Agung Pasir Pengaraian. Peraturan ini dituangkan dalam Peraturan Bupati Rokan Hulu Nomor 18 Tahun 2011 tentang 
Kewajiban Bagi Pegawai Muslim untuk Salat Zuhur dan Salat Asar di Masjid Agung Pasir Pengaraian. Kewajiban salat berjamaah yang dimulai sejak 25 April 2011 ini dilakukan secara serentak di lingkungan pemerintah kabupaten Rokan Hulu. Acara ini langsung dipimpin bupati dan wakilnya. Bupati mengeluarkan kebijakan pemotongan tunjangan transport bagi pegawai yang tiga kali berturut-turut selama satu bulan tidak melaksanakan salat berjamaah (Peraturan Bupati No 18 Tahun 2011).

Penelitian ini menjadi penting untuk melihat pengaruh kebijakan wajib Salat Berjamaah yang diterapkan di Kabupaten Rokan Hulu terhadap etos kerja, sehingga dapat dijadikan sebagai bahan masukan bagi pemerintah daerah lain jika ingin menetapkan kebijakan yang sama sebagai solusi mengatasi degradasi moral yang terjadi saat ini. Penelitian ini juga bisa djadikan referensi untuk pemerintah sebagai salah satu solusi krisis multidimensi. Sehingga dapat dikembangkan ke skala yang lebih luas yaitu di Indonesia sebagai sarana pembinaan moral pemerintah, mengingat sebagian besar penduduk Indonesia yaitu sekitar $87,18 \%$ beragama Islam (Sensus Penduduk BPS 2010).

Berbagai kajian yang menggambarkan relasi antara agama dan etos kerja secara teoritis dan politis telah banyak dilakukan. Acep Mulyadi (2008), menyatakan bahwa Etos kerja harus didasarkan pada tiga unsur, tauhid, taqwa, dan ibadah. Pentingnya etos kerja spiritual dalam peningkatan pengaruh motivasi kerja terhadap kinerja pegawai dikemukakan oleh Mohamad Djasuli dan Gita Arasy Harwadi (2011). Sementara itu Erni Dwi Octaviani dkk. (2011) dalam penelitiannya berhasil membuktikan bahwa ada hubungan positif yang sangat signif kan antara kedisiplinan dengan religuisitas pada anggota Polri. Adapun menyangkut pengaruh antara kebijakan wajib salat berjamaah terhadap etos kerja pegawai pemerintah daerah kabupaten Rokan Hulu, fenomena ini belum tersentuh oleh sebuah penelitian yang utuh.

Berdasarkan latar belakang masalah di atas, maka penulis tertarik untuk melakukan penelitian dan membahasnya dalam bentuk karya tulis yang berjudul : "Pengaruh Kebijakan Wajib Salat Berjamaah Terhadap Etos Kerja Pegawai Daerah Kabupaten Rokan Hulu".

Penelitian ini menjadi penting untuk melihat pengaruh kebijakan wajib Salat Berjamaah yang diterapkan di Kabupaten Rokan Hulu terhadap etos kerja, sehingga dapat dijadikan sebagai bahan masukan bagi pemerintah daerah lain jika ingin menetapkan kebijakan yang sama. Penelitian ini juga bisa djadikan referensi untuk pemerintah sebagai salah satu solusi krisis multidimensi. Sehingga dapat dikembangkan ke skala yang 
lebih luas yaitu di Indonesia sebagai sarana pembinaan moral pemerintah, mengingat sebagian besar penduduk Indonesia yaitu sekitar 87,18\% beragama Islam (Sensus Penduduk BPS 2010).

Berdasarkan uraian dari latar belakang, maka rumusan masalah yang akan diteliti adalah :

1. Apakah terdapat pengaruh kebijakan wajib salat berjamaah terhadap etos kerja pegawai daerah Rokan Hulu?

2. Seberapa besar pengaruh kebijakan wajib salat berjamaah terhadap etos kerja pegawai daerah Rokan Hulu?

3. Tujuan penelitian ini adalah untuk mengetahui apakah terdapat pengaruh kebijakan wajib salat berjamaah terhadap etos kerja pegawai daerah Rokan Hulu dan melihat seberapa besar pengaruh kebijakan wajib salat berjamaah terhadap etos kerja pegawai daerah Rokan Hulu.

\section{TINJAUAN PUSTAKA}

\section{Salat Berjamaah}

Salat memiliki fungsi yang sangat fundamental dalam diri seorang manusia yaitu sebagai benteng dari kemaksiatan, artinya bahwa shalat dapat mencegah perbuatan keji dan munkar. Hal ini diterangkan dalam AlQur'an surat Al-Ankabut ayat 45 : “ Bacalah apa yang telah diwahyukan kepadamu, yaitu Al Kitab (Al Quran) dan dirikanlah shalat. Sesungguhnya shalat itu mencegah dari (perbuatanperbuatan) keji dan mungkar. Dan sesungguhnya mengingat Allah (shalat) adalah lebih besar (keutamaannya dari ibadat-ibadat yang lain). Dan Allah mengetahui apa yang kamu kerjakan."

Salat berjamaah adalah salat yang dilakukan secara bersama, dipimpin oleh seorang imam yang diyakini memenuhi syarat sebagai seorang imam. Makna yang terkandung pada manfaat salat yang dilaksanakan berjamaah adalah untuk belajar disiplin, dan memupuk gotong royong. Salat berjamaah merupakan ibadah yang di dalamnya terkandung unsur kebersamaan yang sangat kuat. Di dalamnya terkandung suatu peluang yang sangat besar untuk saling berkenalan dan bersatu di antara muslimin, yakni saat mereka berjumpa untuk mengerjakan salat lima waktu dan saat masuk maupun keluar dari masjid (Musbikin,2007).

\section{Etos Kerja}

Etos kerja ialah norma-norma yang bersifat mengikat dan ditetapkan secara eksplisit serta praktekpraktek yang diterima dan diakui sebagai kebiasaan yang wajar untuk dipertahankan dan diterapkan dalam kehidupan kekaryaan para anggota suatu organisasi. (Siagian,2002)

Ciri-ciri seseorang yang memiliki etos kerja tinggi dikemukakan oleh 
Biatna Dulbert Tampubolon (2007), bahwa seseorang yang mempunyai etos kerja yang tinggi adalah jika mempunyai penilaian yang sangat positif terhadap hasil kerja manusia, menempatkan pandangan tentang kerja sebagai suatu hal yang amat luhur bagi eksistensi manusia, kerja yang dirasakan sebagai aktivitas yang bermakna bagi kehidupan manusia,kerja dihayati sebagai suatu proses yang membutuhkan ketekunan dan sekaligus sarana yang penting dalam mewujudkan cita-cita, dan kerja dilakukan sebagai bentuk ibadah.

Berbagai kajian yang menggambarkan relasi antara agama dan etos kerja secara teoritis dan politis telah banyak dilakukan. Acep Mulyadi (2008), menyatakan bahwa Etos kerja harus didasarkan pada tiga unsur, tauhid, taqwa, dan ibadah.

Pentingnya etos kerja spiritual dalam peningkatan pengaruh motivasi kerja terhadap kinerja pegawai dikemukakan oleh Mohamad Djasuli dan Gita Arasy Harwadi (2011) .

Sementara itu Erni Dwi Octaviani dkk. (2011) dalam penelitiannya berhasil membuktikan bahwa ada hubungan positifyang sangat signif kan antara kedisiplinan dengan religuisitas pada anggota Polri. Hasil penelitian ini juga didukung oleh M. Yusuf Asry (2008) yang memberikan kesimpulan bahwa pemahaman keagamaan dalam aspek keimanan dan ibadah sosial secara umum memberikan motivasi dan dukungan pada peningkatan etos kerja ekonomi masyarakat Islam yang tinggi.

Kajian secara politis mengenai relasi Islam dan etos kerja sebagai pilihan politik kebijakan pemerintah terungkap dalam tulisan Yahya Muhaimin. Dalam pandangannya, sebagai negara berpenduduk mayoritas Muslim, sudah sepantasnya apabila di masa mendatang pemerintah Indonesia mulaimembuatpolicy untukmengambil dan mengembangkan nilai- nilai yang terkandung dalam ajaran- ajaran Islam sebagai spirit pembangunan bangsa. Hal ini dianggap penting dan signif kan untuk mentransformasikan agama ke dalam aspek kehidupan sosial (Yahya Muhaimin dalam Mulyadi, 2008).

Adapun menyangkut pengaruh antara kebijakan wajib salat berjamaah terhadap etos kerja pegawai pemerintah daerah kabupaten Rokan Hulu, fenomena ini belum tersentuh oleh sebuah penelitian yang utuh.

\section{METODE PENELITIAN}

Penelitian ini merupakan penelitian kuantitatif. Penelitian dilakukan untuk menentukan hubungan kausal ( sebab akibat) yaitu hubungan antara kebijakan wajib salat berjamaah $(X)$ dan etos kerja ( $Y$ ). Pengolahan data penelitian menggunakan bantuan software SPSS 16.0.

\section{Populasi}

Populasi dari penelitian ini adalah seluruh pegawai negri (PNS) muslim 
di lingkungan pemerintah daerah Rokan Hulu pada semua satuan kerja yang diwajibkan salat Zuhur dan Asar berjamaah yaitu sebanyak 1.504 orang. Populasi dalam penelitian ini diasumsikan homogen karena populasi yang diteliti semuanya beragama Islam dan mendapat perlakuan yang sama yaitu sama-sama diwajibkan untuk salat berjamaah.

\section{Sampel dan Teknik Pengambilan Sampel}

Sampel dari penelitian ini adalah sebagian pegawai muslim pemerintah daerah Rokan Hulu yang terkena kebijakan wajib salat Zuhur dan Asar berjamaah di setiap satuan kerja. Jumlah sampel secara keseluruhan yaitu sebanyak 316 pegawai. Teknik pengambilan sampel dilakukan dengan metode cluster random sampling yaitu berdasarkan satuan kerja.

\section{Variabel Penelitian}

a. Independen

Variabel independen atau variabel yang mempengaruhi adalah kebijakan wajib salat berjamaah (X).

b. Dependen

Variabel dependen atau variabel yang dipengaruhi adalah etos kerja (Y).

\section{Hipotesis}

Berdasarkan kajian serta hasil penelitian terdahulu maka hipotesis yang diajukan yaitu kebijakan wajib salat berjamaah berpengaruh positif terhadap etos kerja pegawai pemerintah daerah Kabupaten Rokan Hulu. Pada penelitian ini peneliti menggunakan a sebesar 0.05 .

\section{Sumber Data}

Data yang digunakan dalam karya tulis ini adalah data primer dan data sekunder. Data primer diperoleh dari penelitian yang dilakukan secara langsung dengan menggunakan kuesioner yang disebarkan kepada para pegawai di lingkungan pemerintah daerah kabupaten Rokan Hulu. Sedangkan data sekunder adalah data yang didapatkan dengan cara tinjauan pustaka dan data-data dari lingkungan pemerintahan yang dianggap relevan dan terkait dengan penelitian.

\section{Metode Pengumpulan Data}

a. Interview atau wawancara Melakukan interview atau wawancara terhadap perjabat setempat untukmengetahui latar belakang adanya kebijakan wajib salat berjamaah ini serta gambaran pelaksanaan kebijakan secara garis besar.

b. Kuesioner

Pengumpulan data dengan memberikan kuesioner kepada responden. Kuesioner meliputi pernyataan tentang pengaruh kebijakan wajib salat berjamaah terhadap pengukuran etos kerja sesuai dengan indikator masingmasing variabel. 
Pengaruh Kebijakan Wajib Salat....., Yuni, Wiwit, Rizki, Siti

Tabel 1. Item Pengukuran Variabel Dependen dan Independen

\begin{tabular}{|c|c|}
\hline Variabel & Indikator \\
\hline $\begin{array}{l}\text { Kebijakan Wajib Salat } \\
\text { Berjamaah (X) }\end{array}$ & $\begin{array}{l}\text { - Setuju akan adanya kebijakan wajib salat berjamaah } \\
\text { Zuhur dan Asar } \\
\text { - Sosialisasi Kebijakan yang jelas. } \\
\text { - Sanksi yang wajar. } \\
\text { - Penilaian pegawai akan dampak positif yang ditim- } \\
\text { bulkan pelaksanaan kebijakan. } \\
\text { - Keikhlasan dalam pelaksanaan kebijakan wajib salat } \\
\text { berjamaah } \\
\text { - Optimisme pelaksanaan kebijakan wajib salat berja- } \\
\text { maah akan berpengaruh positif terhadap etos kerja } \\
\text { pegawai }\end{array}$ \\
\hline Etos Kerja (Y) & $\begin{array}{l}\text { - Bekerja dengan tulus dan penuh syukur } \\
\text { - Kebanggan terhadap profesi } \\
\text { - Amanah dan tanggung jawab dalam melayani } \\
\text { masyarakat } \\
\text { - Mengabdi secara serius dalam bekerja } \\
\text { - Kesempurnaan yang diiringi kerendahan hati dalam } \\
\text { bekerja } \\
\text { - Kepuasan terhadap hasil kerja } \\
\text { - Penilaian hasil kerja yang positif oleh atasan } \\
\text { - tidak meninggalkan salat karena pekerjaan } \\
\text { - Teliti dalam bekerja } \\
\text { - Menghindari perlakuan curang } \\
\text { - Disiplin dalam bekerja } \\
\text { - Pengabdian penuh untuk menyelesaikan pekerjaan } \\
\text { yang diamanahkan } \\
\text { - Bersikap lapang dada, menerima kritik dan saran. }\end{array}$ \\
\hline
\end{tabular}

\section{Pengolahan Data}

Menurut Trihendradi (2008), analisis hubungan antar variabel secara garis besar ada dua, yaitu analisis deskriptif dan analisis regresi linier sederhana.

\section{a. Analisis Deskriptif \\ Analisis Deskriptif digunakan untuk melihat gambaran seca-}

ra umum tentang karakteristik responden, menyangkut variabel yang ada. Pada penelitian ini analisis deskriptif digunakan untuk melihat gambaran pendapat para pegawai daerah terhadap kebijakan wajib salat berjamaah. 
b. Analisis Regresi Linier Sederhana

Analisis regresilinier sederhana digunakan untuk mengetahui hubungan atau pengaruh antara variabel kebijakan wajib salat berjamaah $(X)$ dengan variabel etos kerja pegawai (Y) yang ditampilkan dalam bentuk persamaan regresi . Rumus regresi linier sederhana adalah:

$$
\mathbf{Y}=\mathbf{a}+\mathbf{b X}
$$

$\mathrm{Y}=$ Etos kerja (dependen)

$X=$ Kebijakan wajib salat berjamaah (independen)

$\mathrm{a}=$ Nilai konstanta

$b=$ Koef sien regresi
Dengan formula $a$ dan $b$ sebagai berikut:

$\mathrm{a}=\frac{\Sigma X^{2} \Sigma Y-\Sigma X \Sigma(X Y)}{n \Sigma X^{2}-(\Sigma X)^{2}} \quad$ dan $\mathrm{b}=\frac{n \Sigma(X Y)-\Sigma X \Sigma Y}{n \Sigma X^{2}-(\Sigma X)^{2}}$

( Susteyo,2010)

\section{PEMBAHASAN}

\section{Analisis Deskriptif}

Analisis deskriptif pada penelitian ini digunakan untuk melihat gambaran secara umum penilaian para Pegawai Daerah Kabupaten Rokan Hulu terhadap kebijakan wajib salat berjamaah. Penilaiandapatberupapendapattentang kebijakan itu sendiri dan optimisme para pegawai terhadap pengaruh positif yang akan ditimbulkan dengan adanya kebijakan wajib salat berjamaah ini.

\section{Grafik Pendapat Pegawai Tentang Shalat Berjamaah}

wSangat Tidak Setuju = Tidak Setuju =Setuju $=$ Sangat Setuju

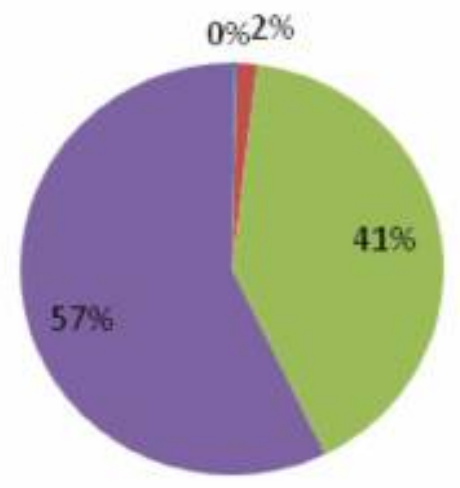

Gambar 1. Deskripsi Pendapat Pegawai Daerah Tentang Adanya Kebijakan Wajib Salat Berjamaah 
Berdasarkan gambar 1 dapat dilihat bahwa sebagaian besar Pegawai Daerah Kabupaten Rokan Hulu menyetujui adanya kebijakan wajib salat berjamaah. Ini terbukti dengan hasil jawaban dari 316 pegawai yang menjadi responden, sebesar $57 \%$ pegawai daerah kabupaten rokan hulu menyatakan sangat setuju dengan kebijakan wajib salat berjamaah dan
$41 \%$ menyatakan setuju dengan kebijakan ini. Sedangkan yang menyatakan tidak setuju hanya $2 \%$ dan $0 \%$ yang menyatakan sangat tidak setuju terhadap kebijakan ini.

Penilaian dan optimisme pegawai daerah tentang dampak positif kebijakan wajib salat berjamaah terlihat pada gambar 2 .

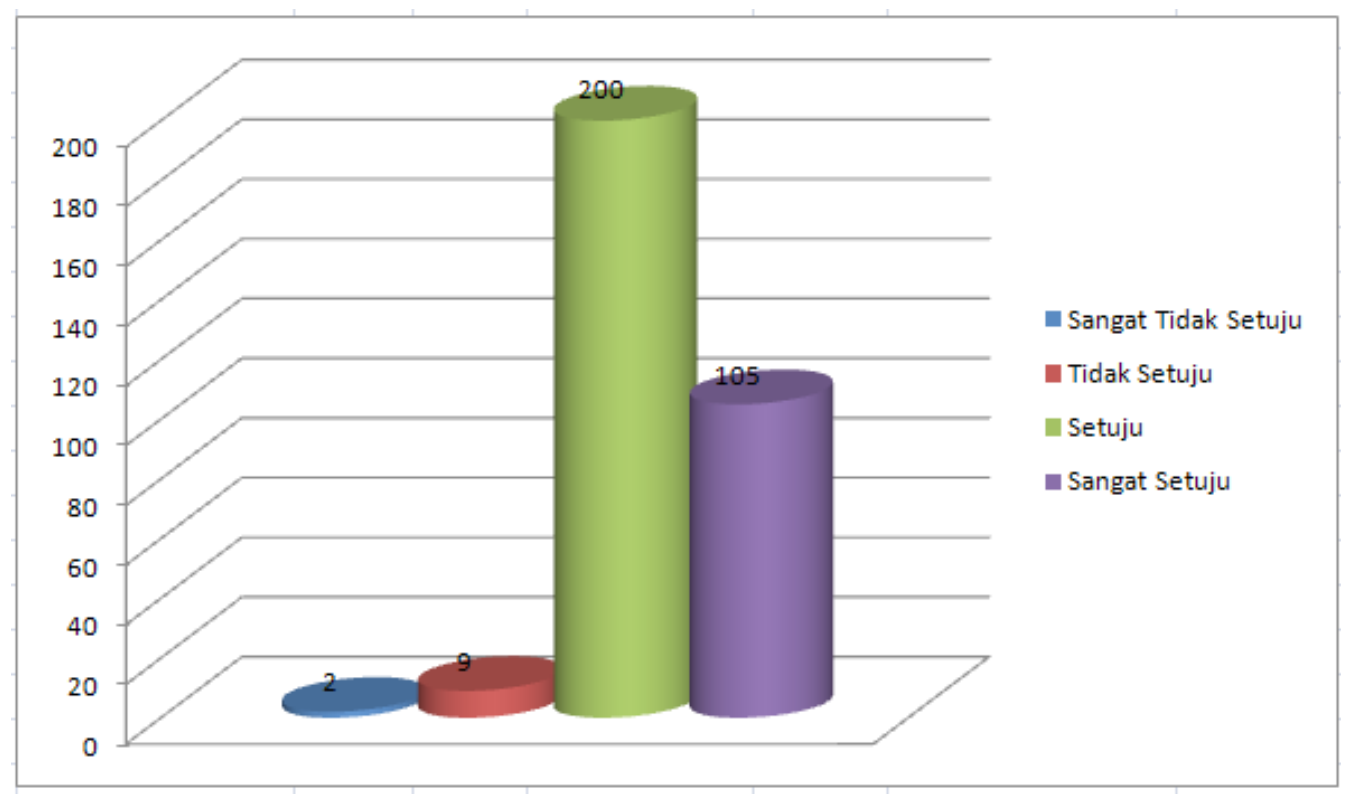

Gambar 2. Penilaian Pegawai Daerah Tentang Dampak Positif Kebijakan Wajib Salat Berjamaah Pada Etos Kerja

Berdasarkan gambar 2. tampak yang ditimbulkan kebijakan salat bahwa pada umumnya para pegawai optimis bahwa kebijakan wajib berjamaah ini terhadap etos kerja. salat berjamaah akan memberikan Dari total 316 pegawai daerah yang menjadi responden dalam penelitian dampak positif terhadap etos kerja. ini, terdapat 200 responden yang Ini dibuktikan dengan banyaknya menyatakan setuju bahwa kebijakan pegawai daerah yang setuju dengan salat berjamaah akan berdampak akan adanya pengaruh positif positif terhadap etos kerja pegawai 
dan 105 responden menyatakan sangat setuju. Sedangkan yang tidak setuju hanya 9 orang dan sangat tidak setuju 2 orang.

Analisis Regresi Linier Sederhana

Analisis regresi linier sederhana digunakan untuk melihat pengaruh variabel independen terhadap variabel dependen. Variabel independen (X) adalah kebijakan wajib salat berjamaah dan variabel dependen $(\mathrm{Y})$ adalah etos kerja. Hasil pengolahan data akhir dapat dilihat pada tabel 2 . dan tabel 3.

Tabel 2. Output ANOVA.

ANOVA $^{b}$

\begin{tabular}{|c|c|c|c|c|c|c|}
\hline \multicolumn{2}{|c|}{ Model } & Sum of Squares & df & Mean Square & $\mathrm{F}$ & Sig. \\
\hline \multirow[t]{3}{*}{1} & Regression & 2519.237 & 1 & 2519.237 & 99.963 & $.000^{a}$ \\
\hline & Residual & 7913.309 & 314 & 25.202 & & \\
\hline & Total & 10432.546 & 315 & & & \\
\hline
\end{tabular}

a. Predictors: (Constant), $X$

b. Dependent Variable: $Y$

Uji secara keseluruhan/ overall menggunakan output Anova yang terdapat pada tabel 2. Pengujian hipotesis pada uji overall yang bertujuan untuk menguji kesesuaian model regresi yang dibentuk berdasarkan variabel dependen dan independen. Model dikatakan sesuai jika nilai P-Value (sig.) $<\alpha$. Dengan pengujian hipotesis sebagai berikut:

Hipotesis :

$\mathrm{H}_{0}: \beta_{1}=0$ ( Model yang digunakan tidak sesuai)

$\mathrm{H}_{1}$ : $\beta_{1} \mathrm{~K} 0$ (Model yang digunakan sesuai)
Taraf keberartian ( $\alpha)$ :

$5 \%$ atau 0.05

Titik kritis :

Tolak $\mathrm{H}_{0}$ jika bila $\mathrm{f}>$ atau P-value(Sig.) $<\alpha$.

Keputusan :

P-value (Sig.) $=0.0000<\alpha=0.05$, maka $\mathrm{H}_{0}$ ditolak.

Dari hasil yang didapat tampak bahwa nilai P-Value (Sig.) pada tabel Anova adalah 0.000 . Nilai ini lebih kecil dari nilai signif kansi yang ditentukan yaitu 0.05 , maka dapat dikatakan model regresi yang dibentuk sudah sesuai. 
Pengaruh Kebijakan Wajib Salat....., Yuni, Wiwit, Rizki, Siti

Tabel[3.[Output $[$ Coef sients

\begin{tabular}{|c|c|c|c|c|c|c|}
\hline \multicolumn{7}{|c|}{ Coeff cients $^{a}$} \\
\hline \multirow{2}{*}{ Model } & & \multicolumn{2}{|c|}{ Unstandardized Coeff cients } & & \multirow{2}{*}{$\mathrm{t}$} & \multirow{2}{*}{ Sig. } \\
\hline & & B & Std. Error & Beta & & \\
\hline 1 & (Constant) & 29.434 & 2.283 & & 12.893 & .000 \\
\hline & $x$ & .843 & .084 & .491 & 9.998 & .000 \\
\hline
\end{tabular}

a. Dependent Variable: $Y$

Hasil pada tabel 3. digunakan untuk menguji pengaruh variabel dependen terhadap variabel independen dengan memperhatikan nilai $\mathrm{P}$-value (Sig.) untuk $\beta_{0}$ dan $\beta_{1}$. Nilai $\beta_{0}$ dan $\beta_{1}$ dikatakan berpengaruh signif kan terhadap variabel dependen jika nilai P-Value yang didapatkan lebih kecil dari $\alpha$.

1. Uji Parsial Konstanta Hipotesis :

$\mathrm{H}_{0}: \beta_{0}=0$ (konstanta tidak signif kan)

$\mathrm{H}_{1}: \beta_{0} \neq 0$ (konstanta signif kan)

Taraf keberartian $(\alpha)$ :

$5 \%$ atau 0.05

Titik kritis :

Tolak $\mathrm{H}_{0}$ jika bila bila $\mathrm{t}>$ atau P-value (Sig.) $<\alpha$.

Keputusan :

P-value (Sig.) $=0.000<\alpha=0.05$, maka $\mathrm{H}_{0}$ ditolak.

Kesimpulan :

Konstanta signif kan.

2. Uji Parsial Kebijakan Wajib Salat Berjamaah

Hipotesis :

$H_{0}: \beta_{1}=0$ ( Koef sien $\beta_{1}$ tidak signif kan)

$H_{1}: \beta_{1} \neq 0$ (Koef sien $\beta_{1}$ signif kan)
Taraf keberartian $(\alpha)$ :

$5 \%$ atau 0.05

Titik kritis :

Tolak $\mathrm{H}_{0}$ jika bila bila $\mathrm{t}>$ atau P-value (Sig) $<\alpha$

Keputusan :

P-value (Sig.) $=0.000<\alpha=0.05$, maka $\mathrm{H}_{0}$ ditolak.

Kesimpulan :

Koef sien $\beta_{1}$ signif kan.

Berdasarkan hasil yang didapat diperoleh nilai P-Value (Sig.) untuk $\beta_{0}$ adalah 0.000 dan nilai $P$-Value (Sig.) untuk $\beta_{1}$ adalah 0.000 . Sehingga dapat disimpukan bahwa nilai $\beta_{0}$ dan $\beta_{1}$ berpengaruh signif kan terhadap variabel dependen, ini karena nilai P-value $($ Sig. $)<0.05$. Sehingga diperoleh model akhir sebagai berikut:

$$
\begin{gathered}
Y=29.434+ \\
0.843 X
\end{gathered}
$$

Dengan :

$$
\begin{aligned}
Y= & \text { Etos Kerja Pegawai Daerah } \\
X= & \text { Kebijakan Wajib Salat } \\
& \text { Berjamaah }
\end{aligned}
$$

Model yang didapat membuktikan bahwa terdapat pengaruh positif kebijakan wajib salat berjamaah 
terhadap etos kerja pegawai daerah Kabupaten Rokan Hulu yaitu sebesar 0.843 . Artinya hipotesis yang diajukan oleh peneliti terbukti.

Pengaruh positif tersebut meliputi bekerjadengantulus dan penuh syukur, kebanggan terhadap profesi, amanah dan tanggung jawab dalam melayani masyarakat, mengabdi secara serius dalam bekerja, kesempurnaan yang diiringi kerendahan hati dalam bekerja, kepuasan terhadap hasil kerja, penilaian hasil kerja yang positif oleh atasan, bekerja dengan tidak meninggalkan salat, teliti, menghindari perlakuan curang dalam bekerja, disiplin, pengabdian penuh untuk menyelesaikan pekerjaan yang diamanahkan, bersikap lapang dada, menerima kritik dan saran, dan tenang dalam melaksanakan pekerjaan.

Jadi dengan peningkatan etos kerja pegawai daerah ini diharapkan juga akan berdampak positif terhadap kinerja pegawai daerah yang akan meningkatkan kualitas pelayanan terhadap masyarakat. Hal ini juga didukung oleh hasil wawancara peneliti dengan bagian Kesejahteraan Rakyat Sekretariat Daerah Kabupaten Rokan Hulu,

Kasubag Kegiatan Keagamaan Setda Rokan Hulu, Bapak Damrah, S.Sos, mengatakan bahwa penerapan kebijakan wajib salat berjamaah zuhur dan ashar merupakan suatu langkah untuk membina akhlak pegawai daerah agar bisa terhindar dari praktek-praktek curang yang saat ini marak terjadi. Menurutnya penanaman nilai-nilai keagamaan menjadi langkah penting yang perlu dilakukan agar tercipta pemerintahan yang bersih dan dalam rangka mencapai visi Rokan Hulu yaitu "Menjadikan Rokan Hulu Sebagai Kabupaten yang terbaik di Propinsi Riau Tahun 2016 dalam rangka menuju Visi Riau 2020".

\section{KESIMPULAN DAN SARAN}

Berdasarkan uraian diatas, maka dapat diperoleh kesimpulan sebagai berikut:

1. Sebagian besar Pegawai Daerah Kabupaten Rokan Hulu menyetujui adanya kebijakan wajib salat berjamaah yang terdapat pada peraturan Bupati Kabupaten Rokan Hulu No 18 Tahun 2011.

2. Sebagian besar Pegawai Daerah Kabupaten Rokan Hulu optimis bahwa kebijakan wajib salat berjamaah yang terdapat pada peraturantersebutakan memberikan dampak positif terhadap etos kerja Pegawai Daerah Kabupaten Rokan Hulu.

3. Terdapat pengaruh positif kebijakan wajib salat berjamaah terhadap etos kerja Pegawai Daerah Kabupaten Rokan Hulu dengan yaitu sebesar 0,843 . Hal ini dapar diartikan bahwa hipotesis yang diajukan oleh peneliti sesuai.

Berdasarkan hasil penelitian yang dilakukan maka rekomendasi yang 
bisa peneliti berikan sebagai saran dalam penelitian ini adalah sebagai berikut :

1. Bagi Pemerintah Daerah Rokan Hulu

Diharapkan dapat mempertahankan kebijakan ini karena terbukti memberikan dampak yang positif terhadap etos kerja, selain itu juga sebaiknya menetapkan berbagai kebijakan lain yang bisa membentuk karakter para pegawai agar tercipta pemerintahan bersih yang memiliki etos kerja tinggi.

2. Bagi Pemerintah Daerah Lain

Sebaiknya pemerintah daerah lain juga mulai melakukan langkahlangkah yang tepat untuk meningkatkan etos kerja para pegawai daerah, salah satunya dapat dengan menerapkan kebijakan yang serupa dengan Kebijakan Wajib Salat Berjamaah Kabupaten Rokan Hulu.

3. Bagi Peneliti Selanjutnya.

Mengingat begitu banyaknya variabel yang bisa dipengaruhi oleh Kebijakan Wajib Salat berjamaah ini, diharapkan peneliti selanjutnya melakukan penelitian dengan variabel dependen yang lebih luas lagi.

\section{DAFTAR PUSTAKA}

Asror, M.Y. 2004. Kaya Karena Allah. Jakarta : Kawan Pustaka.

Asri, M.Y. 2008. 'Pemahaman Keagamaan dan Etos Kerja Ekonomi dalam Masyarakat Islam di Kabupaten Bantul
Yogyakarta', Jurnal Multikulturasi \& Multireligius, vol. VII no. 26 .

Baddu, I. 2007. Pengaruh Etos Kerja Islami Terhadap Kinerja Karyawan. Skripsi publikasi Universitas Brawijaya.

Djasuli, M dan Gita, A.H . 2011. 'Etos Kerja Spritual Sebagai Moderator Hubungan Antara Motivasi Kerja Dengan Kinerja Pegawai Negeri Sipil', Proceeding PESAT (Psik ologi,Ekonomi,Sastra,Arsitektur \&Sipil) Universitas Gunadarma , Vol. 4 Oktober 2011

Dulbert, B.T. 2007. 'Analisis Faktor Gaya Kepemimpinan Dan Faktor Etos Kerja Terhadap Kinerja Pegawai Pada Organisasi Yang Telah Menerapkan SNI 19-90012001', Jurnal Standardisasi, vol. 9, no. 3. pp. 106-11

Dwi, E.O. , Amrizal ,R. , \& Rohmatun. 2011.' Religiusitas dan Kedisiplinan Pada Anggota Polri' , Proyeksi, vol .6 no.2. pp. 62-65. Mulyadi, A .2008 . 'Islam dan Etos Kerja: Relasi Antara Kualitas Keagamaan dengan Etos Produktivitas Kerja di Daerah Kawasan Industri Kabupaten Bekasi' , Turats, vol. 4 no. 1 ,pp 1-19.

Musbikin, I. 2007. Misteri Shalat Berjama'ah. Yogyakarta: Mitra Pustaka.

Nazir. 2005. Metode Penelitian. Jakarta: Ghalia Indonesia.

Priyatno, D. 2008. Mandiri Belajar SPSS. Yogyakarta: MediaKom. 
KHAZANAH, Vol. 6 No.1 Juni 2013

Priyatno,D. 2011. Buku Pintar Statistik Komputer. Yogyakarta : MediaKom.

Riduwan. 2005. Belajar Mudah Penelitian Untuk Guru, Karyawan dan Peneliti Pemula, Bandung: Alfabeta.

Sondang,P. 2002. Kiat Meningkatkan

produktivitas. Jakarta: PT Rineka Cipta.

Susetyo, B. 2010. Statistika untuk Analisis Data Penelitian. Bandung: PT Ref ka Aditama Trihendradi,C. 2008. Step by Step SPSS 16 Analisis Data Statistik. Yogyakarta : ANDI. 